Journal of

Business and Strategic

Management

(JBSM)

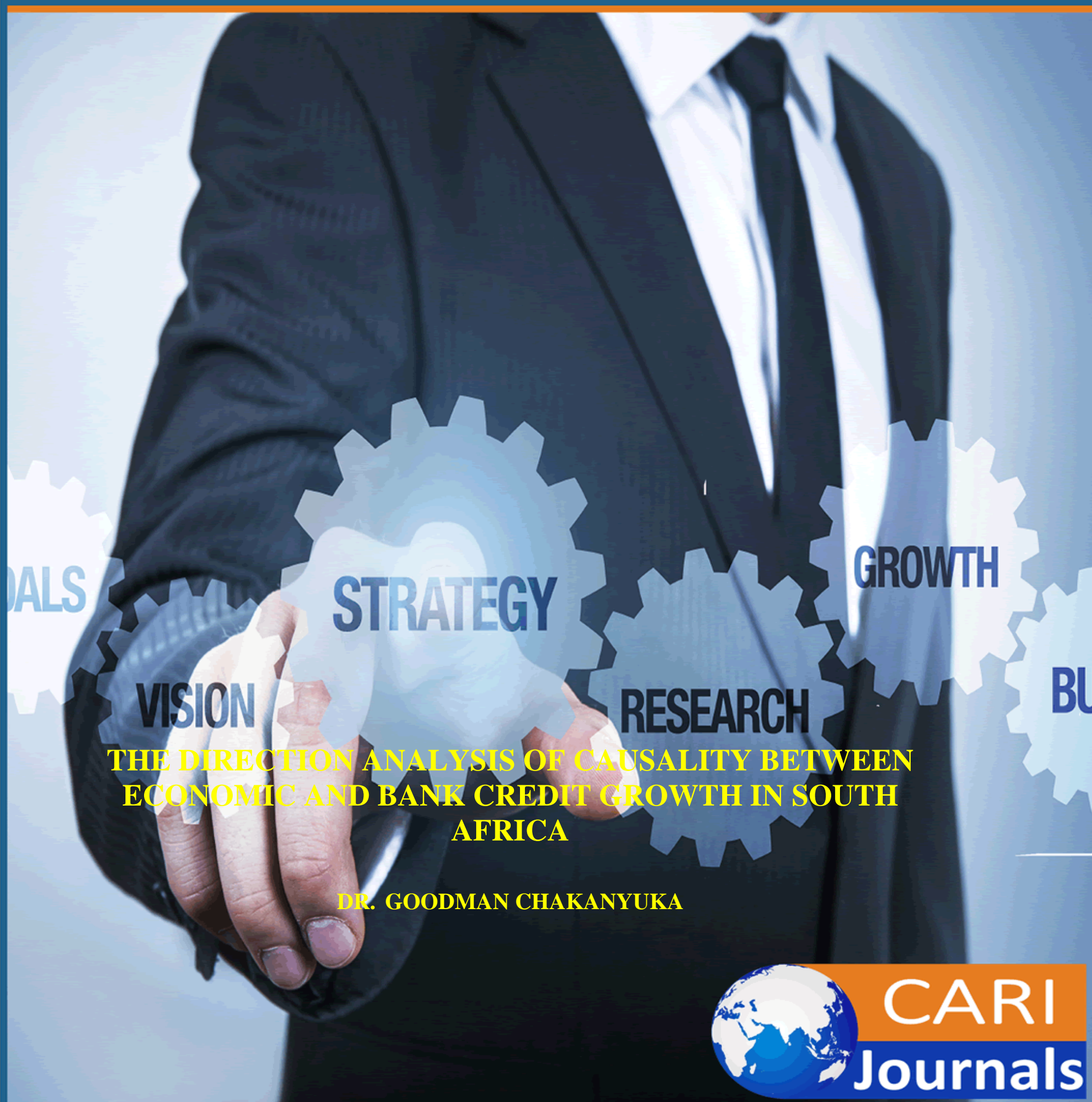




\title{
THE DIRECTION ANALYSIS OF CAUSALITY BETWEEN ECONOMIC AND BANK CREDIT GROWTH IN SOUTH AFRICA
}

\author{
${ }^{1 *}$ Dr. Goodman Chakanyuka \\ University of South Africa \\ *Corresponding Author's Email: goodmanchaks@gmail.com
}

\begin{abstract}
Purpose: The purpose of this study was to analyze of the relationship between business cycles and bank credit extension: evidence from South Africa. The study sought establish the direction of causality between economic growth and bank credit growth in South Africa

Methodology: The econometric methodology was used to augment results of the survey study. Granger causality test technique was applied to the variables of interest to test for direction of causation between variables. The study used quarterly data for the period of 1980: Q1 to 2013: Q4. Business cycles were determined and measured by Gross Domestic Product at market prices while bank-granted credit was proxied by credit extension to the private sector.

Results: Results revealed that there was a stable long-run relationship between macro-economic business cycles and real credit growth in South Africa. The results showed that economic growth significantly caused and stimulated bank credit. The Granger causality test provided evidence of unidirectional causal relationship with direction from economic growth to credit extension for South Africa. The study results indicated that the case for demand-following hypothesis was stronger than supply-leading hypothesis in South Africa. Economic growth spurred credit market development in South Africa.
\end{abstract}

Unique contribution to theory, practice and policy: The study proposes practical policy prescriptions to address challenges currently facing South Africa. The other major contribution of this study is that it shall open new avenues for further research on finding causality of the relationship between various proxies of economic growth and financial development adopting the VAR framework

Keywords: Bank Credit, Business Cycles, Credit Extension, Cointegration, Vector Error Correction Model.

\subsection{INTRODUCTION}

Policymakers and academics closely follow and monitor developments on the credit markets because of the adverse economic effects that often follow episodes of credit booms (Mendoza $\&$ Terrones, 2008). To guarantee macro and financial stability, it is imperative to understand whether, and to what extent, banks are affected by the fluctuations of the macro-economic environment. Quagliariello (2007) argues that on the one hand, if the business cycle does influence banks, financial surveillance may need to be strengthened during recessionary phases, when banks are likely to be more fragile. On other hand, if the response of banks to macroeconomic shocks exacerbates the effects of the downturn, it would be appropriate to establish 
rules aimed at reducing the pro-cyclicality of bank operations (Quagliariello, 2007). The causeand-effect equation of bank-granted credit needs to be understood by policymakers because the pattern of lending may impact the business cycle and therefore the economic growth of the country (Fourie, Botha \& Mears, 2011). The main question that this research sought to answer was what is the causal relationship between business cycles and bank credit extension?

This study investigates and quantifies the causal relationship between business cycles and bank lending in South Africa for the period 1980 to 2013. As argued by Akinboade and Makina (2009), this issue is important because there are variations in bank lending patterns which may coincide with particular business episodes with attendant effect on economic growth of the country. South Africa might offer an ideal case study for an investigation of this nature because of its volatile history both politically and economically (Akinboade \& Makina, 2009). The country has gone through many structural changes since the 1970s. Unlike other countries, it has a fairly developed banking sector that is comparable to the developed countries. This is the rationale of giving an overview on the business cycle episodes and cyclical movements in the banking industry in South Africa

\subsection{Problem Statement}

The speed, severity and geographic reach of the credit crisis of 2007-2009 have renewed the prominence of credit in the rhythm of business cycles (BIS, 2011; Fourie et al., 2011; Rose \& Spiegel, 2009). Before the credit crisis, the role of credit had largely been neglected in monetary policy making (Xu, 2012; Rannenberg, 2012). But crises also offer opportunities. According to Rannenberg (2012), it is now well understood that the interactions between the financial system and the real economy are a weak spot of modern macroeconomics. The ultimate outcome from empirical literature on bank credit channel is clearly articulated in a recent study of the Basel Committee on Bank Supervision. After reviewing the literature, the Committee concluded as follows: A key gap in our knowledge is on the influence of lending on real economic activity [and vice versa]. Specifically, while there is a sizeable body of research on the question of how bank balance sheet positions influence lending, there is significantly less research on the question of how lending affects real activity (BIS, 2011: 39). Researchers and policymakers alike have been left searching for clearer insights (Jorda et al., 2011). In its Global Financial Stability Report, the International Monetary Fund (IMF) argues that the losses incurred by banks caused a contraction in credit supply which in turn contributed to the economic downturn in the United States and beyond (IMF, 2010). These developments have revitalized investigations into the possibility that changes in the supply of credit can amplify the macroeconomic cycle and potentially increases systemic risk. In response to the global crisis, there have been worldwide calls for appropriate policy interventions (Aikman, Haldane \& Nelson, 2011). Evaluating advantages and justifications of these proposals requires full comprehension of causes of and the link between business cycles and credit cycles, which as yet, appear not to having been thoroughly investigated, especially in the developing world. The question of the direction of causality between economic growth and credit extension "has not been adequately addressed" (Basurto, Goodhurt \& Hofman, 2006: 476). Several studies have examined the linkages between bank credit and economic growth (for example Rannenberg, 2012; Fourie et al., 2011; Armistead, 2009; Dell' Ariccia, Igan \& Laeven, 2009; Bordo \& Haubrich, 2009; Kiyotaki \& Moore, 1997; Bernanke \& Lown, 1991). The results have been mixed and conflicting. Moreover, most of these studies have been done in developed countries such as the United States, Canada 
and Australia. Studies on developing countries like South Africa are limited and fragmented (Fourie et al., 2011; Akinboade \& Makina, 2009; Dlamini, 2008; Khomo \& Aziakpono, 2007). Researches carried out by Fourie et al., (2011) and Odhiambo (2004) suggest further research is required on this topical issue and further to compare South African situation to global business cycles.

Clearly, there is theoretical and empirical curiosity in terms of finding the exact nature of the relationship between the financial sector and real economy. Based on the abovementioned, the problem statement of this study was given in the form of a research question as follows: "What is the nature and causal relationship between business cycles and bank credit extension?" In other words, the crucial question, therefore, is whether bank credit market development precedes or follows economic growth in both good and crisis times? In order to answer this question, responses to the following sub-question was required; What is the direction of causality between economic growth and bank credit growth in South Africa?

\subsection{Research Objective}

To determine the direction of causality between business cycles and bank credit extension in South Africa

\subsection{LITERATURE REVIEW}

\subsection{Theoretical Review}

\subsubsection{Holmstrom- Trirole Model}

$\mathrm{Xu}$ (2012) summarizes the main features of the Holmstrom-Trirole Model. In this model, the maximum debt a firm can incur is determined by its networth. It therefore follows that companies with insufficient networth heavily rely on bank credit since they are unable to use direct financing (Holmstrom- Trirole, 1997). Of paramount importance is that financial intermediaries must enhance their project monitoring and supervision activities to mitigate the inherently high risk.

The model then analyzes some of the factors that influence supply and demand for credit. Credit supply is influenced by the strength of banks' balance sheet positions, capital adequacy levels as well as levels and composition of bank deposit liabilities. On the other hand, the net worth of the borrowing firms and collateral offered by existing and potential borrowers influence demand for credit. These scenarios were categorized by Holmstrom and Trirole (1997) as credit squeeze, collateral squeeze and savings squeeze. Seremak (2001) argues that this class of models emphasizes more on credit markets and gives little attention on macroeconomic consequences; consequently, this will not be dealt with extensively here.

\subsubsection{Bernanke, Gertler and Gilchrist (BGG) Model}

The framework is part of the new Keynesian model, and it exhibits a 'financial accelerator' in that endogenous developments in credit markets work to propagate and amplify shocks to the macro-economy (Bernanke \& Gertler, 1999). The key mechanism involves the link between 'external finance premium' (the difference between the cost of funds raised externally and the opportunity cost of funds internal to the firm) and net worth of potential borrowers (defined as the borrower's liquid assets less outstanding obligations). To the extent that borrower's net worth is pro-cyclical (because of the pro-cyclicality of profits and asset prices for example), the 
external finance premium will be countercyclical (Bernanke et al., 1998). Internally generated funds are therefore cheaper than unsecured external borrowings. Moreover, the risk premium is determined by the creditworthiness of the borrower. This particular outcome amplifies the variability of output and investment (Barnejee, 2011).

The other important feature of this model is possibility of exogenous asset price bubbles that can arise because asset prices may be influenced by non-fundamental matters. These nonfundamental factors include pessimism and optimism (Seremak, 2001).

\subsubsection{Kiyotaki-Moore Model}

In the Kiyotaki-Moore Model, imperfection of credit markets lead to imposition of credit limits determined by the value of assets offered as collateral. Lenders have limited power to make borrowers service their loans, unless their borrowings are tangibly secured (Kiyotaki \& Moore, 1997). A theoretical study by Kiyotaki and Moore (1997), cited in Barnejee (2011), showed how credit constraints interact with growth and fluctuations of output over the business cycle. In particular, the dynamic interaction between credit limits and asset prices as collateral for loans is a powerful transmission mechanism by which effects of shocks persist, amplify and spill over to other sectors.

Borrowers' credit limits are determined by value of property offered as security, which affects investment and demand for assets in the economy. Bankers therefore try to align and match maximum credit exposure with intrinsic value of collateral held. This view was also echoed by $\mathrm{Xu}$ (2012). In addition to the demand for credit from firms, Meh and Moran (2004) argue that banks themselves are also subject to frictions in raising loanable funds and show that the supply side of the credit market equation also contributes to shock propagation, affecting output dynamics in the economy.

In a nutshell, Kiyotaki and Moore (1997) observed that lending decisions by financial institutions are largely informed by fluctuation in asset prices, which are offered as collateral by the borrowers. Prices of assets move in tandem with developments in the macroeconomic environment and demand conditions. This collateral requirement magnifies the business cycle. Banerjee (2011) adds that credit rationing can potentially intensify small shocks to the economy, giving rise to large swings in output and can be highly pro-cyclical.

\subsection{Empirical Review}

Patrick (1966) proposed the stage of development hypothesis. This view propounds that the causal relationship between bank credit and economic growth depends on the stage of economic development. A couple of research works on business cycles and bank credit extension support this hypothesis (Odhiambo, 2007; Calderon \& Liu, 2003; Gregorio \& Guidotti, 1994; Jung, 1986). Gregorio and Guidotti (1993) examined the empirical relationship between long-run growth and financial development, measured by the ratio of bank credit to the private sector to GDP. They found that this proxy is positively correlated with growth in a large-cross-country sample, but that its impact changes across countries. The positive effect is particularly strong in middle and low income countries and also in the 1960s than in the 1970s and 1980s. As shown in their findings, the main channel of transmission from credit market development to economic growth is the efficiency, rather than the volume, of investment. They however, also found a 
robust and significant negative correlation between financial intermediation and economic growth in Latin America. The findings support the stage of development hypothesis.

In furtherance of the above studies, Jung (1986) investigated the causal connection credit and economic growth for 56 countries (19 developed and 37 developing). The study provides evidence to show that in developing countries, supply-leading view is more dominant than demand-following view and the opposite is true for developed countries. In a similar study, Calderon and Liu (2003) concluded bank credit contributes more to economic growth in developing countries than developed countries. Again, the results provide support for Patrick's hypothesis of stage of development.

Odhiambo (2007) revealed evidence suggesting that demand-following view reigns in South Africa. It therefore follows that in South Africa, it is the real sector of the economy that creates and promotes demand for credit. The same study found contradicting evidence in Tanzania where it is the availability and growth of bank credit that propel economic growth. The findings of this study are consistent with the stage of development view. This is evident by the fact that there is strong evidence is support of supply-leading response in Tanzania- a country with a comparatively less developed real sector and support for demand-following response in South Africa- a country with a relatively developed real sector.

\subsection{RESEARCH METHODOLOGY}

The econometric methodology is used to augment results of the survey study. Granger causality test technique is applied to the variables of interest to test for direction of causation between variables. The study uses quarterly data for the period of 1980: Q1 to 2013: Q4. Business cycles are determined and measured by Gross Domestic Product at market prices while bank-granted credit is proxied by credit extension to the private sector.

\subsection{RESULTS AND DISCUSSIONS}

\subsection{Response Rate}

The targeted sample was 300 in size. Questionnaires were successfully circulated to 240 respondents. The respondents were drawn from top four banks in terms of loan market share, 163 returned and usable questionnaires out of 240. This response rate was considered adequate.

\subsection{Demographic Information of the Respondents}

The study sought to establish the respondents' experience in the credit and risk management field. Figure 1 overleaf shows that $7 \%$ of the respondents indicated that they had less than 3 years' experience in the credit and risk management field, 19\% indicated that they had 3 to 5 years' relevant experience, $46 \%$ for 6 to 10 years while $28 \%$ stated they had worked in the credit and risk space for more than 10 years. This illustrates that majority of the respondents (74\%) had worked in the credit and risk management field for more than 5 years which suggests that they had been in the field long enough and could therefore offer reliable information as sought by the study. 


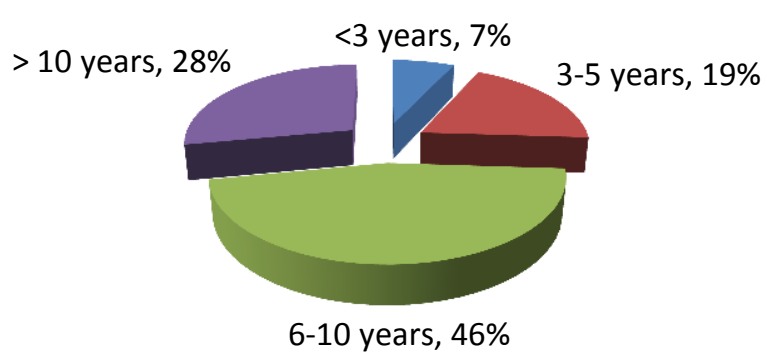

Figure 1: Years of Experience in Credit and Risk Field

\subsection{Causality runs from Business Cycles to Bank Credit Extension}

Table 1 presents data on the level of agreement from respondents on statements suggesting that causality runs from business cycle to bank credit extension. Firstly, respondents were asked to give the extent to which lending standards change in response to variations in the quality of the borrowers over the business cycle. As indicated by a mean score of 4.09, a majority of the respondents agreed with the statement, while a standard deviation of 0.97 indicates that the responses were closer to the mean thus they were similar. In addition, most of the respondents agreed that bank lending is procyclical, that is, it moves in tandem with business cycles as indicated by a mean score of 3.78. The standard deviation of $1.12(\sigma>1)$ indicates that the answers received were not closer to the mean thus they were dissimilar.

Table 1: Causality from Business Cycles to Bank Credit Extension

\begin{tabular}{lll}
\hline Statement & Mean & Std. Dev \\
\hline $\begin{array}{l}\text { Lending standards change in response to variations in the quality of } \\
\text { the borrowers in the business cycle. }\end{array}$ & 4.09 & 0.97 \\
$\begin{array}{l}\text { Bank lending is pro-cyclical i.e. it moves in tandem with business } \\
\text { cycle. }\end{array}$ & 3.78 & 1.12 \\
\hline
\end{tabular}

\subsection{Causality runs from Bank Credit Extension to Business Cycles}

Most of the respondents agreed that availability of bank credit to fund activities of businesses exacerbate the magnitude of business cycles as shown by a mean score of 3.93.

Table 2: Causality from Bank Credit Extension to Business Cycles

\begin{tabular}{llc}
\hline Statement & Mean & Std. Dev \\
\hline $\begin{array}{l}\text { Availability of bank funds to fund activities of business } \\
\text { exacerbates the magnitude of business cycle. }\end{array}$ & 0.69 \\
$\begin{array}{l}\text { Fluctuations in bank credit may have significant, indeed critical, } \\
\text { effects on macro-economic activity and may amplify swings in the } \\
\text { macro-economy. }\end{array}$ & \\
\hline
\end{tabular}

Further, respondents strongly agreed with the statement that fluctuations in bank credit may have significant, indeed critical, effects on macro-economic activity and may amplify swings in the macro-economy as shown by a mean score of 4.51 . As shown in Table 2 the standard deviations 
Journal of Business and Strategic Management

ISSN xxxx-xxxx (Paper) ISSN 2520-0402 (Online)

Vol.1, Issue No.2, pp 42 - 57, 2016

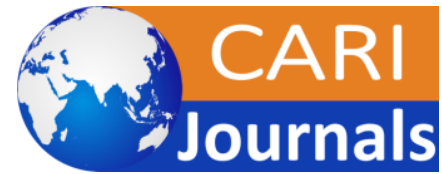

www.carijournals.org

of the responses on both statements were below $1(\sigma<1)$ indicating that the answers received were closer to the respective means thus they were similar.

\subsection{Changes of Credit Standards as Applied to Approval of Loans and Advances}

Respondents were asked to give the extent to which bank credit standards as applied to approval of household and business loans changed during the peak of the 2007-2009 financial crisis. To start with, in the case of households a majority of the respondents indicated that bank standards were tightened somewhat as indicated by a mean score of 2.39 .

Table 3: Changes of Bank Credit Standards

\begin{tabular}{llc}
\hline Statement & Mean & Std.Dev \\
\hline $\begin{array}{l}\text { My bank changed credit standards in regard to approval of loans } \\
\text { and advances to households }\end{array}$ & 2.39 & 1.46 \\
$\begin{array}{l}\text { My bank changed credit standards in regard to approval of loans } \\
\text { and advances to businesses }\end{array}$ & 2.30 & 1.02 \\
$\begin{array}{l}\text { Overall, my bank changed credit standards in regard to approval of } \\
\text { loans and advances to households and businesses }\end{array}$ & 2.42 & 1.46 \\
\hline
\end{tabular}

Secondly, in the case of businesses, a majority of the respondents also indicated that bank standards were tightened somewhat as indicated by a mean score of 2.30 . Thirdly, majority of the respondents indicated that overall, banks somewhat tightened credit standards in regard to approval of loans and advances to households and businesses. The standard deviations of the responses on the three statements were $1.46,1.02$ and 1.46 respectively $(\sigma>1)$, indicating that that the answers received were not closer to the respective means thus they were dissimilar. The data findings are presented in Table 3.

\subsection{Demand for Loans during Bottom of Business Cycle}

Respondents were asked to give the extent to which demand for bank credit changed during the peak of the 2007-2009 financial crisis. Respondents were asked to give the extent to which demand for loans and advances have changed in both households and businesses. To start with, in the case of households, a majority of the respondents indicated that household demand for loans and advances decreased somewhat (mean score $=2.10$ ). Secondly, in the case of businesses, majority of respondents indicated that demand for loans and advances decreased somewhat (mean score $=2.41$ ). Thirdly, in the case of the overall change in credit demand, majority of respondents indicated that demand for loans and advances decreased somewhat (mean score =2.36). As shown in Table 4 below the standard deviations were 1.05, 1.37, 1.17 levels respectively, indicating that the answers received on the three statements were not closer to the respective means thus they were dissimilar.

Table 4: Change in Demand for Loans and Advances during the Financial Crisis

\begin{tabular}{llc}
\hline Statement & Mean & Std. Dev \\
\hline Households demand for loans and advances changed in my bank & 2.10 & 1.05 \\
Businesses demand for loans and advances changed in my bank & 2.41 & 1.37 \\
Overall, the demand for loans and advances changed in my bank & 2.36 & 1.17 \\
\hline
\end{tabular}




\subsection{Econometric Test Results}

As previously stated in Chapter One, the purpose of this study was to establish the nature and causal relationship between business cycles and bank credit extension. In this study, a change in Gross Domestic Product (GDP) at current market rate was used as a proxy for business cycle indicator. The credit extended to the Private (PSCR) in South Africa was modelled against several variables namely; Gross Domestic Product (GDP), Deposit Liabilities (DEP), Money supply (M3), Prime Lending Rate (LR), Inflation (CPI) and Nominal Effective Exchange Rate (NEER).

\subsubsection{Preliminary Analysis}

\section{a) Descriptive Analysis}

Table 5 provides the descriptive statistics of the variables namely, Gross Domestic Product (GDP), Inflation (CPI), Deposits (DEP), Prime lending Rate (LR), Money supply (M3), Nominal Effective Exchange Rate (NEER) and Credit extended to the private sector (PSCR) for the period 1980:Q1 to 2013:Q4. During the period under review, GDP growth averaged $12.92 \%$ with a low of $-3.74 \%$ and a high of $22.60 \%$. Bank credit extended to the private sector averaged $14.96 \%$ recording a maximum of $34.60 \%$ and minimum of $-0.60 \%$ during the same period.

Table 5: Descriptive Statistics

\begin{tabular}{llllllll}
\hline & GDP & CPI & DEP & LR & M3 & NEER & PSCR \\
\hline Mean & 12.92 & 9.63 & 15.44 & 15.41 & 15.04 & 216.70 & 14.96 \\
Median & 15.43 & 9.25 & 12.13 & 15.38 & 12.45 & 136.10 & 15.40 \\
Maximum & 22.60 & 19.70 & 37.14 & 25.50 & 39.90 & 747.58 & 34.60 \\
Minimum & $(3.74)$ & 0.30 & 1.79 & 8.50 & 1.55 & 52.74 & $(0.60)$ \\
Std. Dev. & 4.23 & 4.69 & 7.64 & 4.32 & 7.17 & 198.21 & 6.97 \\
Observations & 136 & 136 & 136 & 136 & 136 & 136 & 136 \\
\hline
\end{tabular}

\section{b) Trend Analysis}

This section provides graphical representation of the movement and changes of the variables under study over the years 1980:Q1 to 2013:Q4. 


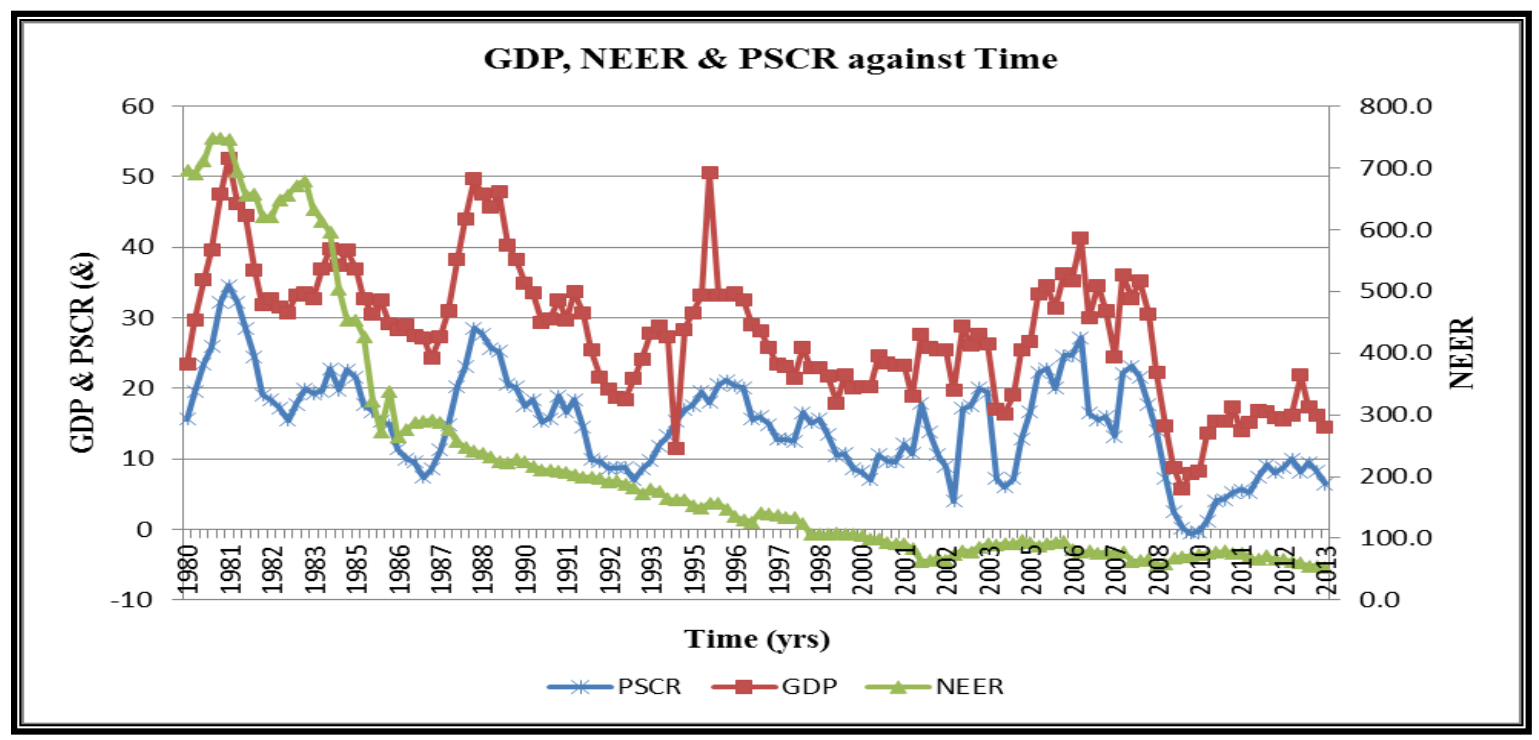

Figure 2: Trend of PSCR, GDP and NEER

A trend analysis of credit to the private sector (PSCR), business cycle indicator (GDP) and exchange rate (NEER) was conducted and results shown in Figure 2. The graph shows an insightful trend between business cycle indicator and the supply of bank credit extended to the private sector over the years. The trend indicates that for the period of study the nominal effective exchange rate was generally downward trending whereas GDP and PSCR were cyclical in nature. When the GDP rose there was a rise in credit to the private sector also implying that there was a positive and pronounced association between the two variables.

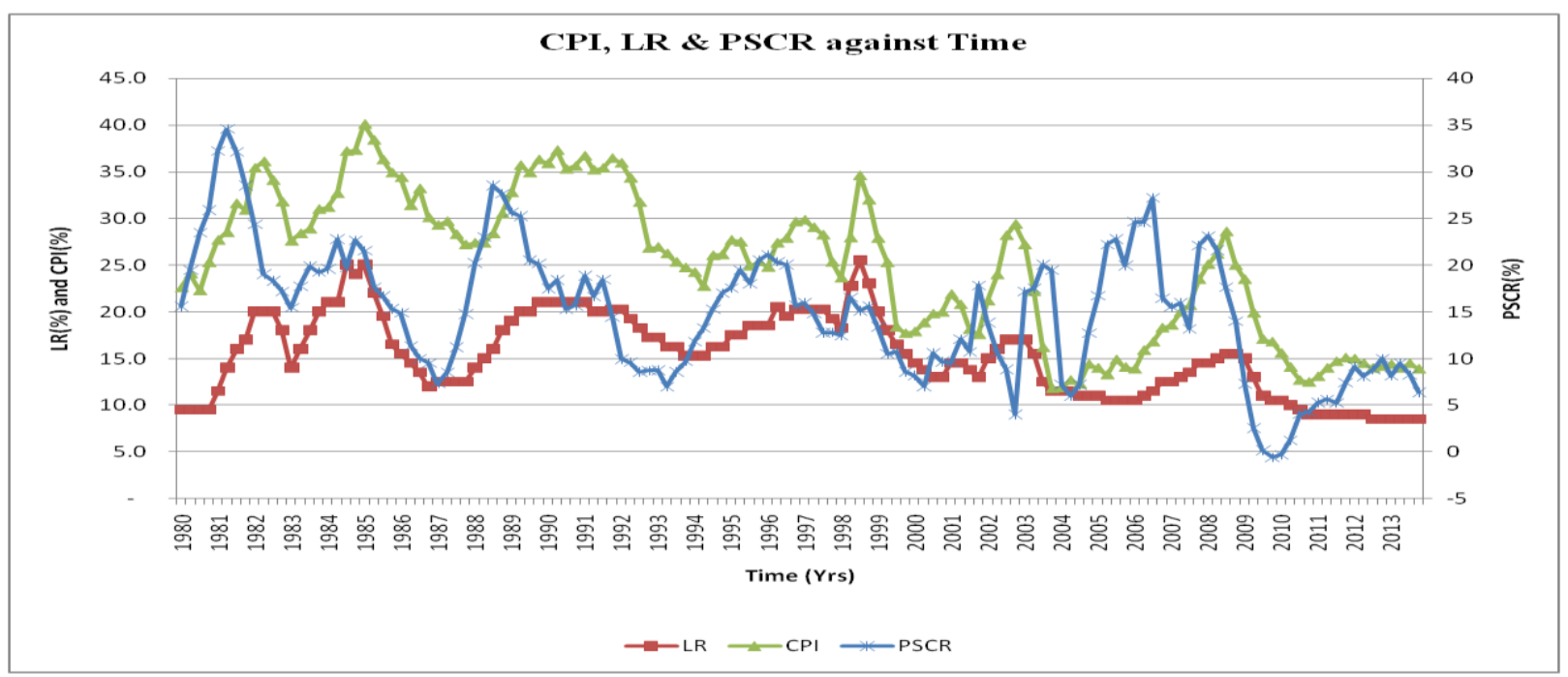

Figure 3 Trend of PSCR, LR and CPI over years

Figure 3 depicts the trend analysis of prime lending rate, inflation and credit to the private sector over the period of study. This trend shows that when inflation rose then there was an accompanying rise in the prime lending rate so was the credit to the private sector. However, from about 2003 to 2010, the pattern changed. Low levels of interest rate and inflation were 
Journal of Business and Strategic Management

ISSN xxxx-xxxx (Paper) ISSN 2520-0402 (Online)

Vol.1, Issue No.2, pp 42 - 57, 2016

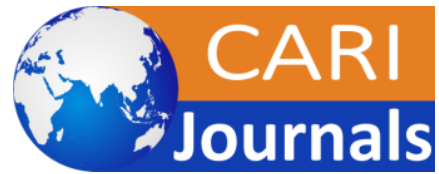

www.carijournals.org

associated with high increases in credit extended to the private sector. In this case an increase in $\mathrm{CPI}$ or prime lending rate also led to the decrease of credit to the private sector and a decline in them led to an increase in the credit to the private sector.

The figure 4 below shows the trend analysis of Money Supply (M3) and PSCR over the entire period of study (1980:Q1- 2013:Q4). From the graphical presentation, the money supply (M3) and PSCR have been fluctuating in tandem since 1980. The rate of growth in money supply however, has been much greater than the change in credit to the private sector. Nonetheless, there is a positive correlation between the two variables. A positive relation is also observed between deposit liabilities (DEP) and credit extended to the private sector.

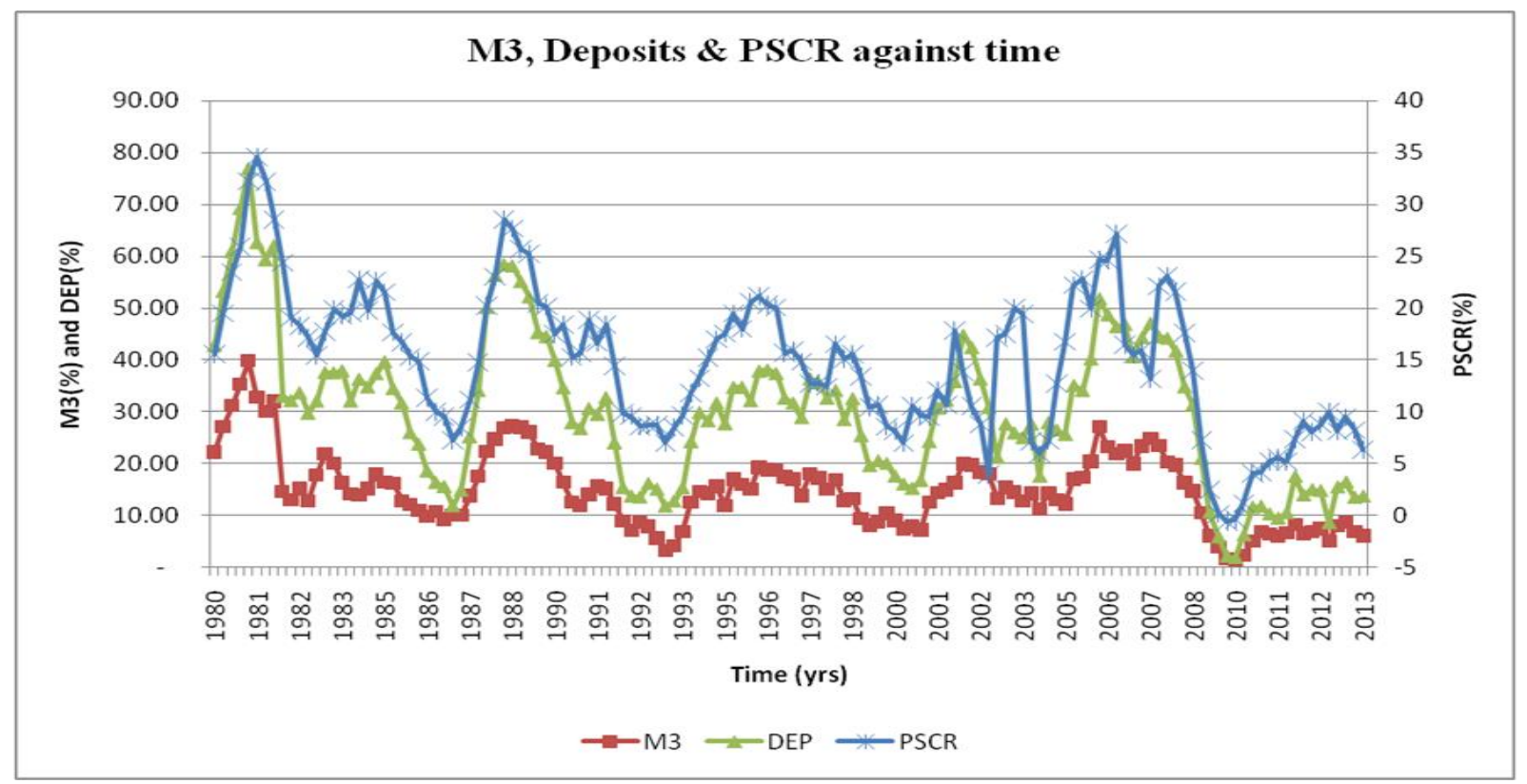

Figure 4: Trend of PSCR, DEP and M3

\subsection{Vector Error Correction Model Test Results (Short Run Results)}

The researcher proceeded to estimate the short run error correction model after having reached conclusion regarding the inherent long run relationships. As shown in Table 7, in the short run, the impact of economic growth on credit extended to the private sector is mixed. The current (DLNGDP) impacts positively while the first lag (DLNLAGGDP) impacts negatively. From the short-supply elasticity of DLNGDP, a short-run increase in economic growth by $1 \%$ induces an increase in credit extended by about $0.11 \%$ in South Africa. However, in the long-run, the magnitude of GDP coefficient is quite small and insignificant ( $\mathrm{p}$-value > 0.5) indicating that business cycles partially determine the magnitude of bank credit extended in the short run. In this case, the null hypothesis of no short-run relationship between the two variables DLNPSCR and DLNGDP is not rejected given that the reported $\mathrm{p}$-value $(\mathrm{p}=0.1192)$ in the short run model is above the $5 \%$ critical value thus leading to the adoption of the null hypothesis of non-existence a short-run relationship. 
Journal of Business and Strategic Management

ISSN xxxx-xxxx (Paper) ISSN 2520-0402 (Online)

Vol.1, Issue No.2, pp 42 - 57, 2016

Table 6: Short-run Relationship

\begin{tabular}{|c|c|c|c|c|}
\hline \multicolumn{5}{|c|}{ Dependent Variable: DLNPSCR } \\
\hline \multicolumn{5}{|c|}{ Method: Least Squares } \\
\hline \multicolumn{5}{|c|}{ Sample(adjusted): 1980:3 2013:4 } \\
\hline \multicolumn{5}{|c|}{ Included observations: 133 after adjusting endpoints } \\
\hline Variable & Coefficient & Std. Error & t-Statistic & Prob. \\
\hline DLNCPI & -0.116015 & 0.218212 & -0.531663 & 0.0276 \\
\hline DLNGDP & 0.106130 & 0.067620 & 1.569520 & 0.1192 \\
\hline DLNLR & -0.074561 & 0.016197 & -4.603528 & 0.0000 \\
\hline DLNM3 & 0.275292 & 0.08815 & 3.124247 & 0.0022 \\
\hline DLNNEER & 0.005472 & 0.011003 & 0.497263 & 0.6199 \\
\hline DLNLAGCPI & 0.012335 & 0.003398 & 3.630207 & 0.0004 \\
\hline DLNLAGGDP & -0.072628 & 0.130048 & -0.450622 & 0.0065 \\
\hline DLNLAGLR & 0.050877 & 0.016589 & 3.066906 & 0.0027 \\
\hline DLNLAGM3 & 0.171539 & 0.078770 & 2.177714 & 0.0314 \\
\hline DLNLAGNEER & 0.017750 & 0.014714 & 1.206325 & 0.2301 \\
\hline DLNLAGPSCR & 0.011688 & 0.086710 & 0.134797 & 0.00894 \\
\hline LAGRESID & -0.105563 & 0.188433 & 0.560215 & 0.00576 \\
\hline $\bar{C}$ & -0.004369 & 0.002735 & -1.597456 & 0.1128 \\
\hline R-squared & 0.785547 & Mean dep & t var & 0.033946 \\
\hline Adjusted R-squared & 0.760317 & S.D. depe & var & 0.022754 \\
\hline S.E. of regression & 0.011140 & Akaike in & erion & 5.200182 \\
\hline Sum squared resid & 0.014768 & Schwarz & & 5.482697 \\
\hline Log likelihood & 420.4436 & F-statistic & & 2.048523 \\
\hline Durbin-Watson stat & 2.044543 & Prob(F-st & & 0.00000 \\
\hline
\end{tabular}

Similarly, the impact of changes of the current and first lag of inflation (CPI) and prime lending rate (LR), on credit extended to the private sector (PSCR) is mixed. Current lending rates (DLNLR) impact negatively while first lag (DLNLAGLR) impacts positively. Both results are highly significant $(\mathrm{p}<0.05)$. The impact of DLNCPI (negative) and DLNLAGCPI (positive) is 
significant ( $\mathrm{p}$-value $=0.0276$ and 0.004 respectively). Money supply variables DLNM3 and DLNLAGM3 have positive coefficients and both are considered significant ( $p$-values $<0.5$ ). This suggests that bank lending is strongly dependent on demand as indicated by cyclical factors such as economic growth and money supply.

Going through the results in Table 4.23 as shown, the variables appeared with the expected signs except for exchange rate (DLNNEER) which was expected to be negative. The result is contrary to major beliefs that exchange rate impacts negatively on the amount of loans that can be extended by commercial banks in South Africa. However, it is important to note that the results of the model suggest that the impact of both DLNNEER and DLNLAGNEER is minimal and insignificant as confirmed by p-values of more than 0.05. By and large, the results indicate that the economic criterion for the model estimation was satisfactory

The coefficient of determination (R-squared) which gives 0.785547 indicates that the model explains $79 \%$ of the variations in the dependent variable DLNPSCR. This result remains robust even after adjusting for degrees of freedom (df) as indicated by the value of adjusted R-squared, which is 0.760317 . Thus the regression has a good fit as only $24 \%$ variation in credit extended to the private sector is left unaccounted for by the model. The F-statistic, a measure of overall significance of the regression is 2.048523. This value is significant at $1 \%, 5 \%$ and $10 \%$ because the calculated Prob (F-statistic) is equal to zero. This is supported by low standard error of regression equation signifying minimized sum of squared error. With this, the hypothesis that all the explanatory variables introduced in the model are not jointly significant in explaining the variations in DLNPSCR was rejected and concluded that they are simultaneously significant, that is, the independent variables have good explanatory power.

The most important parameter when estimating the VECM is the speed of adjustment. The results in Table 6 reveal that the error correction term (ECM-1) is negative and statistically significant at 5\% (p-value $=0.00576)$, which implies that DLNPSCR and measures of DLNPSCR are adjusting to their long run relationship. In other words, this confirms that there is not any problem in the long run equilibrium relationship between the independent and dependent variables at 5\% level of significance. The error correction term relative value $(-0.105563)$ for South Africa shows a satisfactory rate of convergence to the equilibrium state per period. This result implies that there is a negative gradual adjustment (convergence) to the long run equilibrium. The coefficient of $(0.105563)$ indicates that $10.56 \%$ of the disequilibria in the short run PSCR achieved in one period are corrected in the subsequent period. This was buttressed by the first differenced lagged values of the dependent variable DLNLAGPSCR (-1) that is significant at 5\%level. This implies that bank's lending performance of the previous quarter significantly and positively affects the current quarter's performance. The Durbin-Watson statistic of 2.044543 shows that the autocorrelation is inconclusive.

The results of the vector error correction model (VECM) indicate how long it will take for a variable to return to equilibrium in the short run when confronted with a shock. The VECM results indicate a significant short-run equilibrium relationship in the cointegrating equation between credit and the variables in the model. This supports the theory of pro-cyclicality that credit is a "unifying variable which will respond to shocks emanating from the dynamic interaction between macroeconomic variables" (Fourie et al., 2011: 13079). 
Journal of Business and Strategic Management

ISSN xxxx-xxxx (Paper) ISSN 2520-0402 (Online)

Vol.1, Issue No.2, pp 42 - 57, 2016

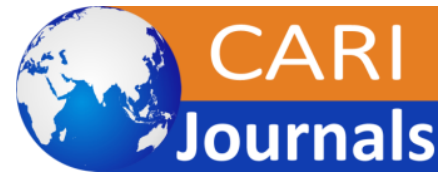

www.carijournals.org

\subsection{Pairwise Granger Causality Tests Results}

Correlation does not tell us anything about the causal relationship between business cycles and bank credit extension. Thus, the Granger causality test was used to examine the direction of the relationship that exists between the variables.

Table 7: Granger Causality Test Results

\begin{tabular}{|l|l|l|l|}
\hline Null Hypothesis & Lags & F-Statistic & Prob. \\
\hline DLNGDP does not Granger cause DLNPSCR & 5 & 0.37509 & 0.04541 \\
DLNPSCR does not Granger cause DLNGDP & 5 & 5.65441 & 0.18853 \\
\hline DLNCPI does not Granger cause DLNPSCR & 5 & 6.15315 & 0.01438 \\
DLNPSCR does not Granger cause DLNCPI & 5 & 0.16674 & 0.68369 \\
\hline DLNLR does not Granger cause DLNPSCR & 5 & 4.29667 & 0.04013 \\
DLNPSCR does not Granger cause DLNLR & 5 & 11.2340 & 0.00105 \\
\hline DLNNEER does not Granger cause DLNPSCR & 5 & 4.33099 & 0.03936 \\
DLNPSCR does not Granger cause DLNNEER & 5 & 3.07777 & 0.08169 \\
\hline DLNM3 does not Granger cause DLNPSCR & 5 & 9.65166 & 0.00232 \\
DLNPSCR does not Granger cause DLNM3 & 5 & 7.91018 & 0.00567 \\
\hline DLNCPI does not Granger cause DLNGDP & 5 & 11.6700 & 0.00084 \\
DLNGDP does not Granger cause DLNCPI & 5 & 0.48382 & 0.48792 \\
\hline DLNLR does not Granger cause DLNGDP & 5 & 76.1105 & $1.0 \mathrm{E}-14$ \\
DLNGDP does not Granger cause DLNLR & 5 & 0.75803 & 0.38553 \\
\hline DLNNEER does not Granger cause DLNGDP & 5 & 0.00356 & 0.95254 \\
DLNGDP does not Granger cause DLNNEER & 5 & 1.10101 & 0.29596 \\
\hline DLNM3 does not Granger cause DLNGDP & 5 & 0.46050 & 0.49858 \\
DLNGDP does not Granger cause DLNM3 & 5 & 5.51689 & 0.02032 \\
\hline
\end{tabular}

In order to proceed to Granger causality test and find direction of causation between the key variables of interest (PSCR and GDP) in the environment of VAR, the researcher used the lag length of 5 as determined by Akaike Information Criterion (AIC). The results of the Granger causality test are presented in Table 8 .

The results show that the null hypothesis that business cycle (GDP) does not Granger cause bank credit extension (PSCR) is rejected at 5\% level (p-value < 0.05). However, the null hypothesis that bank credit extension does not Granger cause business cycles cannot be rejected at 5\% level since $\mathrm{p}$-value $>0.5$. The implication is that there is a unidirectional causal relationship from economic growth to bank credit in South Africa. Therefore, the increase in bank granted credit is a cause of economic growth in South Africa.

The results further provide evidence of unidirectional causalities running from inflation (CPI) to PSCR, from CPI to GDP, from prime lending rate (LR) to GDP, from GDP to money supply (M3) and from exchange rate (NEER) to credit extension (PSCR). Table 8 also shows evidence 
Journal of Business and Strategic Management

ISSN xxxx-xxxx (Paper) ISSN 2520-0402 (Online)

Vol.1, Issue No.2, pp 42 - 57, 2016

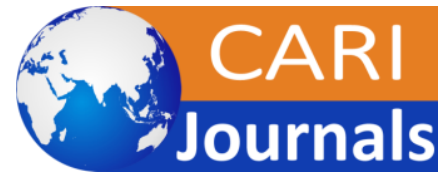

www.carijournals.org

of bi-directional causality between LR and PSCR as well as between M3 and PSCR. However, there is no evidence to support the existence of causality between the remaining pair of variables.

\subsection{DISCUSSION CONCLUSIONS AND RECOMMENDATIONS}

\subsection{Findings}

Majority of the respondents claimed that direction of causality is from economic growth to credit extension and argument for reverse causality was considered weak. The Granger causality analysis in the VAR framework suggests that there is unidirectional causal relationship between business cycles and bank credit extension with direction running from economic growth to bank credit in South Africa. Overall, the study provides evidence to show that there is a long-run relationship between business cycles and bank credit extension. In addition, it is shown that economic growth significantly causes bank credit. There is strong evidence suggesting that economic growth precedes credit extension. There is little and weak evidence of statistical precedence of credit to business cycle frequencies in South Africa. The results lend some support to the demand-following view initially postulated by Robinson (1952) and confirmed by Demetriades and Hussien (1996).

\subsection{Areas of Further Study}

Further research in this area may use a different econometric model, such as the Sim's test, and compare the results with the current study. Moreover, to test robustness of the study's findings, future research may employ variance decomposition for relative importance of explanatory variables and impulse-response function for impact analysis.

\section{REFERENCES}

Akinboade, O. A. \& Makina, D. (2009). Bank lending and business cycle: South African evidence. African Development Review, 21 (3), 476-498.

Akinboade, O. A. \& Makina, D. (2010). Econometric analysis of bank lending and business cycles in South Africa. Journal of Applied Economics, 42(29), 3803-3811, First Publication on 16 Jan 2009 (iFirst).

Bernanke, B. S. (1983). Nonmonetary effects of the financial crisis in the propagation of the great depression. Am. Econ. Rev., 1983(73): 257-276.

Bernanke, B. S. (2006). Monetary aggregates and monetary policy at the federal reserve: A historical perspective." Speech at the Fourth ECB Central Banking Conference, Frankfurt, Germany, November 10, 2006.

Bernanke, B. S. \& Gertler, M. (1995). Inside the black box: The credit channel of monetary policy transmission.” Journal of Economic Perspectives 9(4): 27-48. 
Bernanke, B. S. \& Lown, C. S. (1991). The credit crunch, Brooking Papers on Economic Activity, 205-239.

Bernanke, B., Gertler, M., \& Gilchrist, S. (1994). The financial accelerator and the flight to quality. Review of Economics and Statistics, 78, 1-15.

Bordo, M. D., \& Haubrich, J. G. (2009). Credit market turmoil, monetary policy and business cycles: A historical view. Federal Reserve Bank of Cleveland, Working Paper 15389, available on http://www.nber.org/papers/wi5389

Dell'Ariccia, G., Igan, D., \& Laeven, L. (2009). Credit booms and lending standards: Evidence from the Subprime Mortgage Market. European Banking Centre Discussion Paper No. 2009-145.

Dlamini, S. N (2008). Bank Credit Extension to the private sector and inflation in South Africa. (Unpublished Master's Thesis, Rhodes University).

Fourie, L., Botha, I., \& Mears, R. (2011). Credit extension in South Africa: A business cycle perspective for the period 1985 to 2009. African Journal of Business Management, 5(34), 13074-13083, 28 December 2011.

Holmstrom, B., \& Tirole, J. (1997). Financial intermediation, loanable funds, and the real sector. Quarterly Journal of Economics, 112, 663-691

Jorda, O., Schularic, M. H. P., \& Taylor, A. M. (2011). When credit bites back: Leverage, business cycles and crises. NBER Working Paper 17621. Available

Khomo, M. M., \& Aziakpono, M. J. (2007). Forecasting recession in South Africa: A comparison of the yield curve and other economic indicators. South African Journal of Economics, 75(2), 194-211.

Kiyotaki, N., \& Moore, J. (1997). Credit cycles. Journal of Political Economy, 105(2), 211-48.

Marcus, G. (2011). Statement of the monetary policy committee” SARB, MPC 21 July 2011. 
Marcus, G. (2013). Statement of the monetary policy committee” SARB, MPC 20 March 2013.

Meh, C., \& Moran, K. (2004). Bank capital, agency costs and monetary policy," Discussion Paper.

Mendoza. E. G., \& Terrones, M. E (2008). An anatomy of credit booms: Evidence from macro aggregates and firm level data. Financial Cycles, Liquidity and Securitization Conference, 18 April, 2008, IMF.

Odhiambo, N. M. (2004). Is financial development still a spur to economic growth? A causal evidence from South Africa. Savings and Development, 28(1), 47-62.

Owens, R. E., \& Schreft, S. L. (1993). Identifying credit crunches. Federal Reserve Bank, Richmond Economic Review, Working Paper, 93-2.

Patrick, T. H. (1966). Financial development and economic growth in undeveloped countries. Economic Development and Cultural Change, 14, 174-189

Quagliariello, M. (2007). Banks' riskiness over the business cycle: a panel analysis on Italian intermediaries". Applied Financial Economics, 17, 119-138.

Rannenberg, A. (2012). Asymmetric information in credit markets, bank leverage cycles and macroeconomic dynamics. Working Paper Research No. 224 April 2012, National Bank of Belgium.

Rannenberg, A. (2012). Asymmetric information in credit markets, bank leverage cycles and macroeconomic dynamics. Working Paper Research No. 224 April 2012, National Bank of Belgium.

Seremak, V. (2001). Credit cycles- theory and application on the Czech Republic. January 2001.

$\mathrm{Xu}, \mathrm{T}$. (2010). The role of credit in international business cycles. Bank of Canada Working Paper 212-36, November 2012. 